\title{
Mesozooplankton and copepod community structures in the southern East China Sea: the status during the monsoonal transition period in September
}

\author{
Li-Chun Tseng • Hans-Uwe Dahms • \\ Qing-Chao Chen $\cdot$ Jiang-Shiou Hwang
}

Received: 14 April 2011/Revised: 4 February 2012/ Accepted: 10 February 2012/Published online: 25 February 2012

(C) Springer-Verlag and AWI 2012

\begin{abstract}
A field sampling was conducted before the onset of the northeasterly monsoon to investigate the copepod community composition during the monsoon transition period at the northern coast of Taiwan (East China Sea). In total, 22 major mesozooplankton taxa were found, with the Calanoida (relative abundance: $66.36 \%$ ) and Chaetognatha $(9.44 \%)$ being the most abundant. Mesozooplankton densities ranged between 226.91 and 2162.84 individuals $\mathrm{m}^{-3}$ (mean \pm SD: $744.01 \pm 631.5$ individuals $\mathrm{m}^{-3}$ ). A total of 49 copepod species were identified, belonging to 4 orders, 19 families, and 30 genera. The most abundant species were: Temora turbinata (23.50\%), Undinula vulgaris (17.92\%), and Acrocalanus gibber (14.73\%). The chaetognath Flaccisagitta enflata occurred at all 8 sampling stations, providing a $95 \%$ portion of the overall chaetognath contribution. Amphipoda were abundant at stations 4 and 5, with Hyperioides sibaginis and Lestigonus bengalensis being dominant,
\end{abstract}

Communicated by Heinz-Dieter Franke.

Li-Chun Tseng and Hans-Uwe Dahms are contributed equally to the present contribution.

L.-C. Tseng · J.-S. Hwang ( $\varangle)$

Institute of Marine Biology, National Taiwan Ocean University,

2 Pei-Ning Road, Keelung 20224, Taiwan

e-mail: jshwang@mail.ntou.edu.tw

L.-C. Tseng

e-mail: lichun@mail.bestredeye.org

H.-U. Dahms

Green Life Science Department, College of Convergence,

Sangmyung University, Seoul 110-743, Korea

Q.-C. Chen

South China Sea Institute of Oceanology,

Chinese Academy of Science, Guangzhou, China and comprising about $50 \%$ of all amphipods. Chaetognath abundance showed a significantly negative correlation with salinity ( $r=0.77, p=0.027$ ), whereas mesozooplankton group numbers had a significantly positive correlation with salinity ( $r=0.71, p=0.048$ ). Densities of four copepod species (Calanus sinicus, Calocalanus pavo, Calanopia elliptica and Labidocera acuta) showed a significantly negative correlation with seawater temperature. Communities of mesozooplankton and copepods of northern Taiwan varied spatially with the distance to land. The results of this study provide evidence for the presence of $C$. sinicus in the coastal area of northern Taiwan during the early northeast monsoon transition period in September.

Keywords Mesozooplankton · Copepod · East China Sea $\cdot$ Monsoon transition period

\section{Introduction}

The marine biota in the waters around the island of Taiwan is highly diverse. It has been estimated that around $10 \%$ of the world's marine species can be found in waters around Taiwan (Shao 1998). Several authors explained this high biodiversity as being caused by the convergence of several large water masses (Jan et al. 2002; Hwang et al. 2010a; Tseng et al. 2011a). Copepod communities in Taiwan waters are highly influenced by water masses from ocean currents (Hwang et al. 2004, 2006, 2010b; Dur et al. 2007; Tseng et al. 2008b, d, e; Lan et al. 2009). Temperate species are transferred from the north and tropical species from the south via the Taiwan Strait, affecting the mesozooplankton communities on the west coast of Taiwan (Hwang et al. 2004, 2006, 2009; Dur et al. 2007; Tseng et al. 2008a, e). 
The Kuroshio Current flows from the equator via the east coast of the Philippines and brings warm water masses all along the east coast of Taiwan year round. In this manner, many warm water species from the south reach the western and northern coastal areas of Taiwan (Hsiao et al. 2004; Hwang et al. 2007; Tseng et al. 2008a, b, e). In the Taiwan Strait and at the southern edge of the East China Sea (ECS), water circulation is strongly influenced by the prevailing monsoonal winds and their seasonal changes (Lee and Chao 2003; Tseng et al. 2008b). During the northeast (NE) monsoon period in winter and spring (September to March), the China Coastal Current (CCC) brings cold water masses from the Bohai Sea, the Yellow Sea and the ECS to the Taiwan Strait (Wong et al. 2000; Liang et al. 2003; Lo et al. 2004a; Zuo et al. 2006; Tseng et al. 2008b). The southwest (SW) monsoon brings species from the South China Sea during summer and autumn (April to August) to the south of Taiwan (Lo et al. 2001; Liao et al. 2006; Tseng et al. 2008b; Lan et al. 2004, 2009).

Such complex water exchange affects the composition and abundance of oceanic biota around the island of Taiwan. This also holds for microzooplankton (Vandromme et al. 2010; Chang et al. 2011) and the mesozooplankton dominated by copepods (Liao et al. 1999; Tseng et al. 2008e). Pelagic copepods are important food sources for fish (Dahms and Hwang 2007; Mahjoub et al. 2011) and likely play a pivotal role in the transfer of matter and energy in the southern Taiwan Strait (Tseng et al. 2008c) and in the northern South China Sea (Tseng et al. 2009).

Zooplankton communities have long been applied as indicators of water movements (Hwang and Wong 2005; Dahms and Hwang 2010). In northern Taiwan, long-term studies of copepod successions showed that Calanus sinicus is an important indicator species for cold water masses from the Bohai Sea and the Yellow Sea (Hwang et al. 2004, 2006; Dur et al. 2007). Hwang et al. (2004) described C. sinicus as rare in samples from July to September, but the species appeared again in October, dramatically increasing in density and occurrence ratio. As yet, however, it is not known when exactly $C$. sinicus reaches the coastal areas of northern Taiwan from the north. The present study aimed to characterize the mesozooplankton community and copepod assemblages during the southwest (SW)-northeast (NE) monsoon transition period in northern Taiwan waters because this appears to be an important period for community alterations.

\section{Materials and methods}

Field sampling

For the present study, we selected the coastal waters of the southern ECS in the vicinity of Taipei County of northern
Table 1 Locations and dates/day times of sampling on cruise ORIICR488 (2-3/September/1998)

\begin{tabular}{llll}
\hline Station & $\begin{array}{l}\text { Latitude } \\
(\mathrm{N})\end{array}$ & $\begin{array}{l}\text { Longitude } \\
(\mathrm{E})\end{array}$ & $\begin{array}{l}\text { Date } \\
\text { (September/day time) }\end{array}$ \\
\hline 1 & $25^{\circ} 09.809^{\prime}$ & $121^{\circ} 46.520^{\prime}$ & $02 / 18: 04$ \\
2 & $25^{\circ} 14.957^{\prime}$ & $121^{\circ} 40.355^{\prime}$ & $02 / 19: 17$ \\
3 & $25^{\circ} 21.717^{\prime}$ & $121^{\circ} 47.054^{\prime}$ & $02 / 20: 59$ \\
4 & $25^{\circ} 27.666^{\prime}$ & $121^{\circ} 52.105^{\prime}$ & $02 / 22: 32$ \\
5 & $25^{\circ} 33.546^{\prime}$ & $121^{\circ} 58.469^{\prime}$ & $03 / 00: 25$ \\
6 & $25^{\circ} 39.874^{\prime}$ & $122^{\circ} 04.830^{\prime}$ & $03 / 02: 00$ \\
7 & $25^{\circ} 45.529^{\prime}$ & $122^{\circ} 10.716^{\prime}$ & $03 / 03: 48$ \\
8 & $25^{\circ} 51.256^{\prime}$ & $122^{\circ} 16.918^{\prime}$ & $03 / 06: 00$ \\
\hline
\end{tabular}

Taiwan. The sampling stations included one station near Bi-Sar Harbor (northern Taiwan) and seven stations located on the transect between northern Taiwan and Pengjiayu Island in the southern ECS, between $25^{\circ} 09.809^{\prime}-25^{\circ} 51.256^{\prime} \mathrm{N}$ and $121^{\circ} 40.355^{\prime}-122^{\circ} 16.918^{\prime} \mathrm{E}$ (Table 1, Fig. 1).

A research cruise was conducted in September 1998, i.e. before the onset of the northeasterly monsoon. Zooplankton samples were collected at the 8 selected stations by surface tows $(0-5 \mathrm{~m})$ with a standard North Pacific zooplankton net (mouth diameter $45 \mathrm{~cm}$, mesh size $333 \mu \mathrm{m}$ ) provided with a flow meter in the center of the net opening (Hydrobios; Kiel, Germany). Samples were preserved immediately in $5 \%$ buffered formaldehyde in seawater. Prior to plankton collection, salinity and temperature were measured on board. In the laboratory, samples were split by a Folsom splitter until the subsample contained less than 500 specimens. Copepods and mesozooplankton were sorted and identified at the species level using the identification aids of Chen and Zhang (1965), Chen et al. (1974) and Chihara and Murano (1997). Additional original papers were used for species identification if required.

\section{Statistical analyses}

Species density matrices were analyzed using multivariate analyses for copepod species. Non-metric cluster analysis was performed together with the Bray-Curtis similarity index after logarithmic transformations of species abundance data. Significance levels of copepod assemblages between stations were calculated using a similarity program provided by the Plymouth Routine in Multivariate Ecological Research (PRIMER), version IV software package (Clarke and Warwick 1994). The abundance of copepod species of whole samples were used for the calculation of similarities before clustering. The functional test of Box and Cox (1964) for the transformation of data was applied before the similarity analysis. The value $(\lambda)$ of the power transformation was set as 0.95 , and the $\log$ $(x+1)$ was applied to treat the individual densities of all samples. 
Fig. 1 Map of the sampling stations on cruise ORII-CR488 during 2-3/September/1998

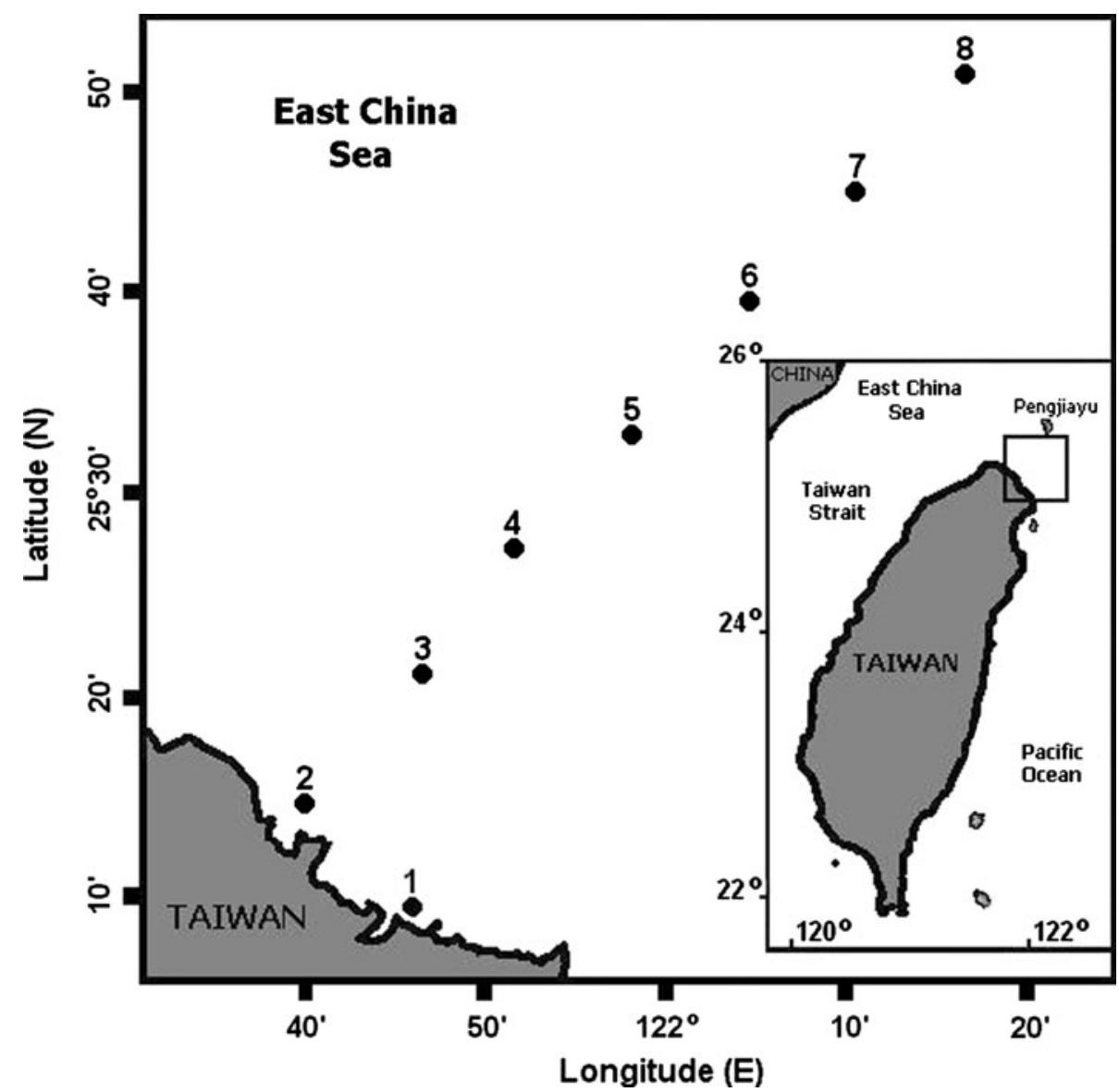

The copepod species characterizing each cluster were further identified using the Indicator Value Index (IndVal) proposed by Dufrêne and Legendre (1997). This index is obtained by multiplying the product of two independently computed values by 100 :

$\operatorname{IndVal}(j, s)=100 S P(j, s) F I(j, s)$

where $(S P j, s)$ is the specificity, and $(F I j, s)$ is the fidelity of a species $(s)$ towards a group of samples $(j)$, and these are calculated by:

$S P(j, s)=\frac{N I(j, s)}{\Sigma N I(s)} ; \quad F I(j, s)=\frac{N S(j, s)}{\Sigma N S(s)}$

where $N I(j, s)$ is the mean abundance of species $s$ across samples pertaining to $j, \Sigma N I(s)$ is the sum of the mean abundances of species $s$ within the various groups in the partition, $N S(j, s)$ is the number of samples in $j$ where species $s$ is present, and $\Sigma N S(s)$ is the total number of samples in that group. The specificity of a species for a group is greatest if a species is present only in a particular group, whereas the fidelity of a species to a group is greatest if the species is present in all samples of the group considered. Here, we only considered values of $S P(j, s)$ above $5 \%$ of each cluster grouping for the calculation of the IndVal indices. To evaluate copepod assemblages for the present sampling period, an analysis of indicator species was applied to each sampling cruise separately.

The Shannon-Wiener diversity index was used to evaluate species diversity, and Pielou's evenness was used to measure the relative abundance of species at each station. The relationship between copepod abundance and temperature and salinity was studied with Pearson's product moment correlation.

\section{Results}

Hydrographic and weather conditions

In September 1998, the monthly-averaged sea surface temperature (SST; satellite images from NOAA) in the area north of Taiwan showed values higher than $28^{\circ} \mathrm{C}$ (Fig. 2). In northeastern Taiwan (southern ECS), where water masses are derived from the Kuroshio Current flowing along the eastern Philippines, the surface waters in September 1998 had temperatures even higher than $30^{\circ} \mathrm{C}$. In the area of the northern Taiwan Strait, the CCC brings colder waters from the ECS into the Taiwan Strait, and the 
Fig. 2 Satellite image showing the monthly-averaged surface seawater temperature in September 1998

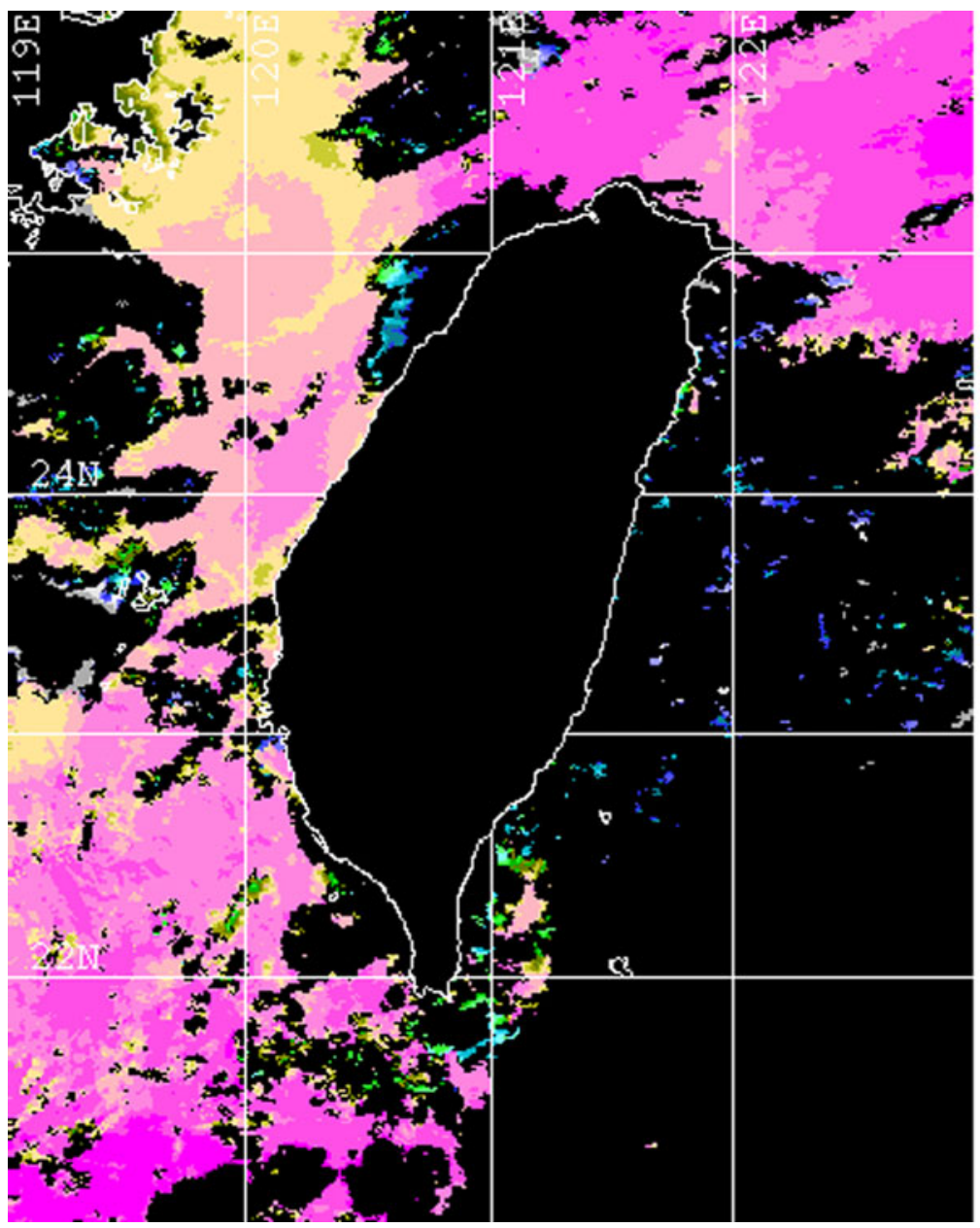

water temperatures were about $26-27^{\circ} \mathrm{C}$. The slight variations in salinity and water temperature among stations are shown in Fig. 3a. The water temperature at a depth of $5 \mathrm{~m}$ ranged from $26.75^{\circ} \mathrm{C}$ (station 5) to $28.56^{\circ} \mathrm{C}$ (station 1); the average temperature of all sampling stations was $27.85 \pm 0.59^{\circ} \mathrm{C}$. The salinity at a depth of $5 \mathrm{~m}$ ranged between 33.49 (station 2) and 34.19 (station 7) (Fig. 3b). The average salinity of all sampling stations was $33.77 \pm 0.28$. The salinities were lowest at stations 1 and 2 of the coastal area and showed an increase with distance to the coastline of Taiwan (particularly at stations 3 to 8 ). The salinity variation among stations was affected by freshwater from the island mixed with waters of the Kuroshio Current (Fig. 2). A temperature-salinity diagram characterizes the water masses at each sampling station (Fig. 3b). The similarities in the temperature/salinity profiles indicate that waters at all sampling stations belonged to the same water mass.

Figure 4 shows the daily averages (recorded every hour) of air temperature, wind direction, and wind speed from $1 /$ July/1998 to the $1 /$ January/1999. Data were retrieved from the automatic monitoring instrument of the Central Weather Bureau at Keelung City, Ministry of
Transportation and Communications, Taiwan. Keelung City is located in northeastern Taiwan adjacent to the sampling area. During the recording period, the daily average temperature varied from $17.2^{\circ} \mathrm{C}$ (11/December) to $32.6^{\circ} \mathrm{C}$ (20/July). The air temperature in summer (July and August) was higher than $29.0^{\circ} \mathrm{C}$ (Fig. 4a). The temperature showed a decreasing trend from July to the end of 1998. The wind direction followed the monsoonal changes ( 0 and 360 degree means wind coming from the north, 90 degree means wind from the east, etc.) (Fig. 4b). The SW monsoon prevails in summer (July to mid-September) and the NE monsoon from mid-September to the end of December. During the SW monsoon period air temperatures were higher than during the NE monsoon period. A transition period occurred during September. Most records of wind direction before September belonged to the SW monsoon and this changed during the NE monsoon after September. The daily average wind speed varied from 1.1 to $7.5 \mathrm{~ms}^{-1}$. Both lowest (October 21 and December 21) and highest (October 16) wind speeds were recorded, when the NE monsoon prevailed (Fig. 4c). Wind speeds during the SW monsoon period were lower than $6 \mathrm{~ms}^{-1}$ before 

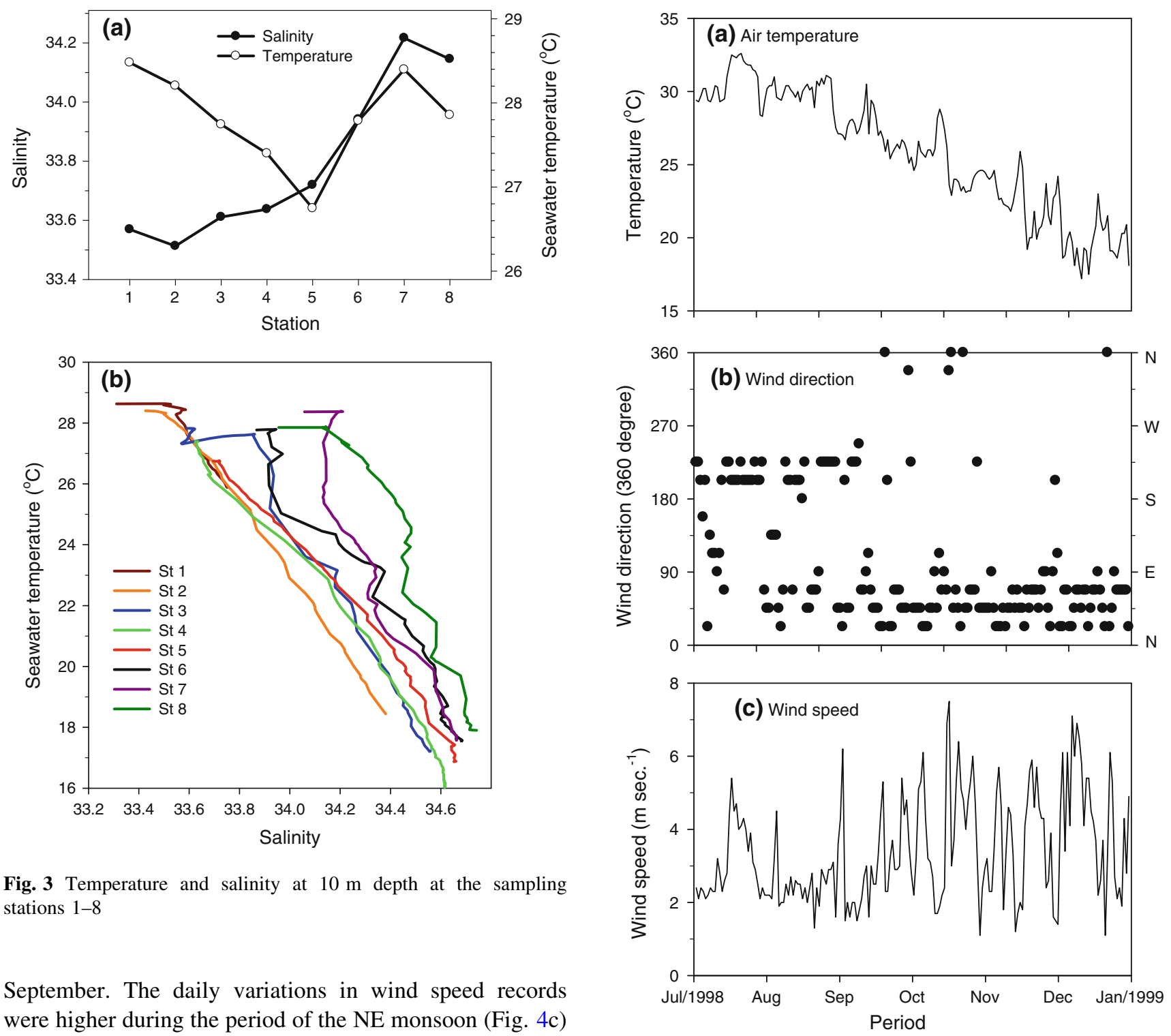

September. The daily variations in wind speed records were higher during the period of the NE monsoon (Fig. 4c) from September onwards.

\section{Mesozooplankton composition and abundance}

Among the samples from the 8 stations, we identified 22 mesozooplankton groups (Table 2). The numerically dominant groups were calanoid copepods (relative abundance $66.36 \%$ ) and chaetognaths $(9.44 \%$ ), which together comprised $75.80 \%$ of the overall mesozooplankton counts (Table 2). Figure 5 shows, for each sampling station, total abundance and number of groups (Fig. 5a) as well as the proportions of the six top dominant groups (Fig. 5b). Both total abundance values and numbers of groups varied clearly among stations. The mesozooplankton densities ranged between 226.9 (station 6) and 2162.8 (station 5) individuals $\mathrm{m}^{-3}$, and the average was $744.0 \pm 631.5$ individuals $\mathrm{m}^{-3}$. Station 5 showed the highest density values of mesozooplankton, which correlated with the

Fig. 4 Air temperature (a), wind direction (b) and wind speed (c) during the period from 1/July/1998 to the 1/January/1999 (information from the automatic monitoring instrument of the Central Weather Bureau at Keelung City, Ministry of Transportation and Communications, Taiwan)

lowest temperature of all stations. The numbers of mesozooplankton group ranged between 7 (station 3) and 18 (station 6) station $^{-1}$, averaging $13.25 \pm 3.92$ station $^{-1}$. Thus, station 6 showed the lowest mesozooplankton density, but the highest group number in this sampling cruise. There was no correlation between density and number of groups ( $r=-0.410, p=0.313$, Pearson's correlation). Five mesozooplankton groups were dominant in the present study: Calanoida, Chaetognatha, other Decapoda (i.e. decapods except of Lucifer larvae, Table 2), Poecilostomatoida and Amphipoda (Fig. 5b). At all sampling stations, calanoid copepods were the most dominant group, 
Table 2 Abundance (mean $\pm \mathrm{SD}$ ), relative abundance (RA) and occurrence ratio $(\mathrm{OR})$ of each mesozooplankton group recorded on cruise ORII-CR488 (2-3/September/1998)

\begin{tabular}{|c|c|c|c|}
\hline Group & $\begin{array}{l}\text { Abundance } \\
\text { (individuals } \mathrm{m}^{-3} \text { ) }\end{array}$ & $\begin{array}{l}\text { RA } \\
(\%)\end{array}$ & $\begin{array}{l}\text { OR } \\
(\%)\end{array}$ \\
\hline Medusae & $3.2 \pm 5.85$ & 0.43 & 62.5 \\
\hline Polychaeta & $1.45 \pm 2.97$ & 0.19 & 50.0 \\
\hline Sagitta spp. & $70.23 \pm 49.6$ & 9.44 & 100.0 \\
\hline Cladocera & $0.64 \pm 1.49$ & 0.09 & 25.0 \\
\hline Ostracoda & $0.61 \pm 1.48$ & 0.08 & 37.5 \\
\hline Copepod nauplii & $0.03 \pm 0.08$ & 0.00 & 12.5 \\
\hline Calanoida & $493.74 \pm 450.54$ & 66.36 & 100.0 \\
\hline Cyclopoida & $0.56 \pm 1.49$ & 0.07 & 25.0 \\
\hline Harpacticoida & $0.03 \pm 0.08$ & 0.00 & 12.5 \\
\hline Poecilostomatoida & $23.61 \pm 27.49$ & 3.17 & 100.0 \\
\hline Amphipoda & $22.32 \pm 55.57$ & 3.00 & 50.0 \\
\hline Lucifer larvae & $12.71 \pm 12.74$ & 1.71 & 87.5 \\
\hline Euphausiacea & $0.82 \pm 1.22$ & 0.11 & 37.5 \\
\hline Mysidacea & $1.99 \pm 3.01$ & 0.27 & 50.0 \\
\hline Other Decapoda & $49.45 \pm 77.32$ & 6.65 & 75.0 \\
\hline Pteropoda & $21.47 \pm 15.43$ & 2.89 & 100.0 \\
\hline Echinoderm larvae & $0.75 \pm 1.3$ & 0.10 & 37.5 \\
\hline Appendicularia & $8.34 \pm 13.23$ & 1.12 & 75.0 \\
\hline Thaliacea & $11.24 \pm 8.4$ & 1.51 & 100.0 \\
\hline Fish eggs & $1.17 \pm 1.62$ & 0.16 & 50.0 \\
\hline Fish larvae & $1.29 \pm 1.6$ & 0.17 & 50.0 \\
\hline Other larvae & $18.38 \pm 28.31$ & 2.47 & 87.5 \\
\hline
\end{tabular}

with a contribution ranging from $42.99 \%$ (station 6) to $78.39 \%$ (station 8). Decapods showed higher abundance values at stations 4,5 and 6 , with contributions of $30.77 \%$, $7.75 \%$ and $13.18 \%$, respectively (Fig. 5b). Chaetognaths were identified at all eight sampling stations. The dominant species was Flaccisagitta enflata (Grassi 1881), amounting to $95 \%$ of all chaetognath samples. The second most abundant species was Serratosagitta pacifica (Tokioka 1940) (2-3\%), and other species were Ferosagitta ferox (Doncaster 1902), F. robusta (Doncaster 1902), Mesosagitta minima (Grassi 1881), Decipisagitta decipiens (Fowler 1905), Aidanosagitta delicate (Tokioka 1939), A. neglecta (Aida 1897), and A. regularis (Aida 1897), with a relative abundance of around $2-3 \%$ of the chaetognath samples (Fig. 5b). Amphipoda were abundant at stations 4 and 5. The two most abundant amphipod species were represented by Hyperioides sibaginis (Stebbing 1888) and Lestigonus bengalensis Giles 1887; they had a relative abundance of around 50\% of the amphipod samples, followed by Lestrigonus schizogeneios (Stebbing 1888) with $21 \%$. Other amphipods belonging to the genera Lestrigonus, Hyperioides and Hyperietta showed a contribution of around $20 \%$ to the amphipod samples (Fig. 5b). The densities of calanoid copepods were positively correlated with
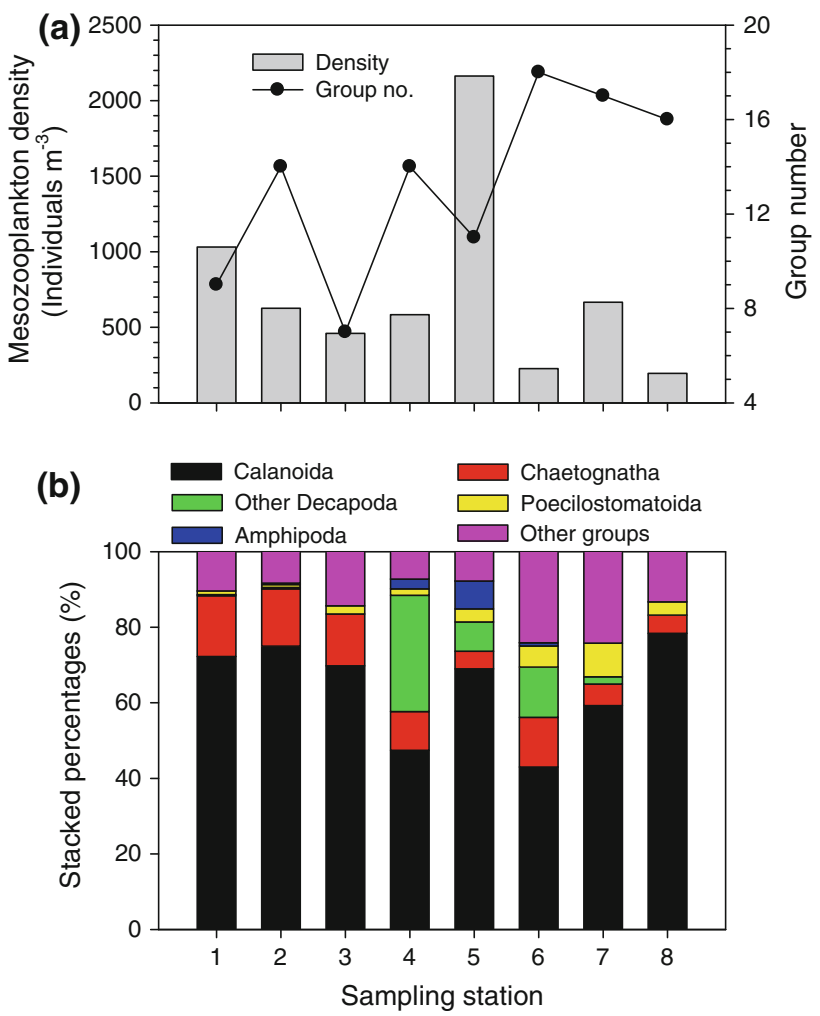

Fig. 5 Mesozooplankton recorded at stations 1-8; a mesozooplankton density and numbers of mesozooplankton groups; $\mathbf{b}$ relative abundance (proportion) of the 6 most dominant groups

total mesozooplankton abundance $(r=0.999, p<0.001$, Pearson's correlation), indicating that calanoid copepods were the dominant group of mesozooplankton in the southern ECS during the monsoon transition period.

Copepod diversity and abundance

From the 8 stations, we identified 49 copepod species. They belonged to 4 orders, 19 families, and 30 genera (Table 3). Figure 6 shows the variation in copepod abundance and species number (Fig. 6a), as well as in species richness, diversity index and evenness index (Fig. 6b) among sampling stations. Total copepod densities ranged between 110.24 (station 6) and 1567.64 (station 5) individuals $\mathrm{m}^{-3}$, with a mean of $517.94 \pm 470.02$ individuals $\mathrm{m}^{-3}$. It showed a similar variation over the sampling stations as total mesozooplankton abundance, with highest values at station 5, where surface temperature was lowest. The copepod species numbers ranged between 16 (stations 1 and 2) and 34 (station 8), with a mean of $21.38 \pm 6.37$ species station ${ }^{-1}$ (Fig. 6a). Copepod densities showed no clear trend over the sampling stations $(r=-0.225$, $p=0.592$, Pearson's correlation), but the species number increased significantly with the distance from the coastline of Taiwan ( $r=0.875, p=0.004$, Pearson's correlation). 
Table 3 Abundance (mean $\pm \mathrm{SD}$ ), relative abundance (RA) and occurrence ratio (OR) of each copepod species recorded on cruise ORII-CR488 (2-3/September/ 1998)

\begin{tabular}{llll}
\hline Species & $\begin{array}{l}\text { Abundance } \\
\left.\text { (individuals } \mathrm{m}^{-3}\right)\end{array}$ & $\begin{array}{l}\text { RA } \\
(\%)\end{array}$ & $\begin{array}{l}\text { OR } \\
(\%)\end{array}$ \\
\hline
\end{tabular}

\section{Calanoida}

Acartiidae

Acartia(Odontacartia) erythraea Giesbrecht 1889

\begin{tabular}{|c|c|}
\hline $0.11 \pm 0.30$ & 0.02 \\
\hline $0.87 \pm 2.29$ & 0.17 \\
\hline $3.37 \pm 5.72$ & 0.65 \\
\hline $59.52 \pm 49.02$ & 11.49 \\
\hline $2.02 \pm 2.99$ & 0.39 \\
\hline $3.95 \pm 8.92$ & 0.76 \\
\hline $92.8 \pm 85.44$ & 17.92 \\
\hline
\end{tabular}

Acartia(Plantacartia) negligens Dana 1849

Calanidae

Calanus sinicus Brodsky 1965

Canthocalanus pauper (Giesbrecht) 1888

Cosmocalanus darwini (Lubbock) 1860

Nannocalanus minor (Claus) 1863

Undinula vulgaris (Dana) 1849

Calocalanidae

Calocalanus pavo (Dana) 1849

Calocalanus plumulosus (Claus) 1863

$2.9 \pm 3.42$

0.56

62.50

$0.03 \pm 0.08$

0.01

12.50

Candaciidae

Candacia bradyi A. Scott 1902

Candacia catula (Giesbrecht) 1889

Candacia ethiopica (Dana) 1849

Paracandacia truncata (Dana) 1849

Centropagidae

Centropages furcatus (Dana) 1849

Centropages orsini Giesbrecht 1889

Clausocalanidae

Clausocalanus arcuicornis (Dana) 1849

Clausocalanus furcatus (Brady) 1883

Clausocalanus mastigophorus (Claus) 1863

Eucalanidae

Pareucalanus attenuatus (Dana) 1849

Rhincalanus rostrifrons (Dana) 1852

Subeucalanus crassus (Giesbrecht) 1888

$0.95 \pm 1.83$

0.18

25.00

$0.27 \pm 0.76$

0.05

12.50

$0.05 \pm 0.15$

0.01

12.50

$0.56 \pm 1.49$

0.11

25.00

$10.55 \pm 17.24$

2.04

87.50

$0.56 \pm 1.00$

0.11

37.50

$9.81 \pm 15.4$

1.89

50.00

$0.51 \pm 1.15$

0.10

25.00

$0.26 \pm 0.52$

0.05

25.00

$0.56 \pm 1.49$

0.11

25.00

$0.03 \pm 0.08$

0.01

12.50

$0.03 \pm 0.08$

0.01

12.50

$21.61 \pm 20.43$

4.17

100.00

Euchaetidae

Euchaeta indica Wolfenden 1905

Euchaeta plana Mori 1937

Euchaeta rimana Bradford 1973

Lucicutiidae

Lucicutia flavicornis (Claus) 1863

Metridinidae

Pleuromamma gracilis (Claus) 1863

Paracalanidae

Acrocalanus gibber Giesbrecht 1888

Acrocalanus gracilis Giesbrecht 1888

Acrocalanus monachus Giesbrecht 1888

Paracalanus parvus (Claus) 1863

Pontellidae

Calanopia elliptica (Dana) 1849

Calanopia minor A. Scott 1902

Labidocera acuta (Dana) 1849

Labidocera minuta Giesbrecht 1889

Pontellina plumata (Dana) 1849

\begin{tabular}{|c|c|c|}
\hline $0.35 \pm 0.98$ & 0.07 & 12.50 \\
\hline $2.25 \pm 3.52$ & 0.43 & 37.50 \\
\hline $0.18 \pm 0.51$ & 0.03 & 12.50 \\
\hline $0.15 \pm 0.42$ & 0.03 & 12.50 \\
\hline $0.2 \pm 0.56$ & 0.04 & 12.50 \\
\hline $76.29 \pm 130.81$ & 14.73 & 87.50 \\
\hline $38.35 \pm 32.48$ & 7.40 & 100.00 \\
\hline $0.97 \pm 1.49$ & 0.19 & 50.00 \\
\hline $3.52 \pm 4.20$ & 0.68 & 87.50 \\
\hline $7.09 \pm 11.05$ & 1.37 & 75.00 \\
\hline $10.32 \pm 13.02$ & 1.99 & 87.50 \\
\hline $8.46 \pm 17.45$ & 1.63 & 50.00 \\
\hline $0.41 \pm 1.15$ & 0.08 & 12.50 \\
\hline $1.05 \pm 2.96$ & 0.20 & 12.50 \\
\hline
\end{tabular}


Table 3 continued

\begin{tabular}{|c|c|c|c|}
\hline Species & 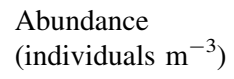 & $\begin{array}{l}\text { RA } \\
(\%)\end{array}$ & $\begin{array}{l}\text { OR } \\
(\%)\end{array}$ \\
\hline \multicolumn{4}{|l|}{ Scolecithricidae } \\
\hline Scolecithrix danae (Lubbock) 1856 & $0.58 \pm 1.49$ & 0.11 & 25.00 \\
\hline \multicolumn{4}{|l|}{ Temoridae } \\
\hline Temora discaudata (Giesbrecht) 1889 & $10.54 \pm 23.46$ & 2.03 & 62.50 \\
\hline Temora turbinata (Dana) 1849 & $121.71 \pm 148.08$ & 23.50 & 100.00 \\
\hline \multicolumn{4}{|l|}{ Cyclopoida } \\
\hline \multicolumn{4}{|l|}{ Oithonidae } \\
\hline Oithona setigera (Dana) 1849 & $0.56 \pm 1.49$ & 0.11 & 25.00 \\
\hline \multicolumn{4}{|l|}{ Harpacticoida } \\
\hline \multicolumn{4}{|l|}{ Miraciidae } \\
\hline Macrosetella gracilis (Dana) 1847 & $0.03 \pm 0.08$ & 0.01 & 12.50 \\
\hline \multicolumn{4}{|l|}{ Poecilostomatoida } \\
\hline \multicolumn{4}{|l|}{ Corycaeidae } \\
\hline Corycaeus(Corycaeus) speciosus Dana 1849 & $1.04 \pm 1.70$ & 0.20 & 50.00 \\
\hline Corycaeus(Ditrichocorycaeus) asiaticus F. Dahl 1894 & $0.15 \pm 0.42$ & 0.03 & 12.50 \\
\hline Corycaeus(Ditrichocorycaeus) dahli Tanaka 1957 & $1.01 \pm 1.59$ & 0.20 & 37.50 \\
\hline Corycaeus(Farranula) gibbula Giesbrecht 1891 & $2.34 \pm 3.00$ & 0.45 & 50.00 \\
\hline Corycaeus(Onychocorycaeus) pumilus M. Dahl 1912 & $1.17 \pm 1.69$ & 0.23 & 50.00 \\
\hline \multicolumn{4}{|l|}{ Oncaeidae } \\
\hline Oncaea venusta Philippi 1843 & $16.22 \pm 23.22$ & 3.13 & 87.50 \\
\hline \multicolumn{4}{|l|}{ Sapphirinidae } \\
\hline Copilia mirabilis Dana 1849 & $1.66 \pm 2.89$ & 0.32 & 62.50 \\
\hline Sapphirina nigromaculata Claus 1863 & $0.03 \pm 0.08$ & 0.01 & 12.50 \\
\hline
\end{tabular}
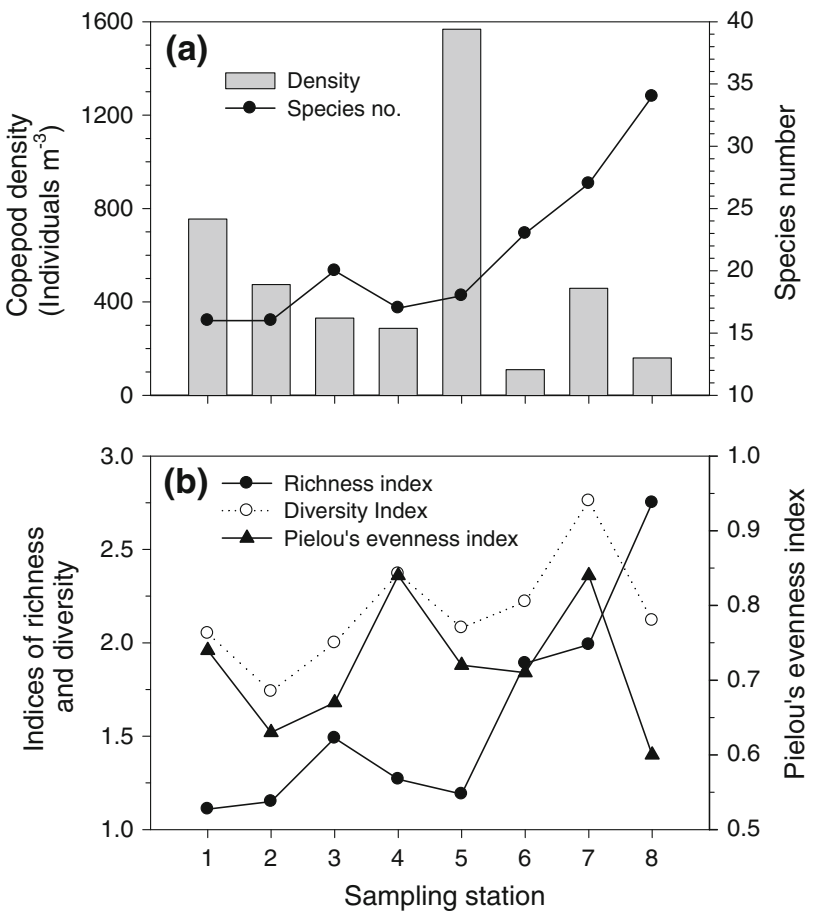

Fig. 6 Copepods recorded at stations 1-8; a copepod density and species number; b richness, evenness and Shannon-Wiener diversity index
The copepod species richness, Shannon-Wiener diversity and evenness indices differed among sampling stations (Fig. 6b). The richness index ranged from 1.11 (station 1) to 2.75 (station 8), and the average value was $1.61 \pm 0.57$. The evenness index ranged between 0.6 (station 8) and 0.84 (station 4 and 7), with a mean of $0.72 \pm 0.09$. The Shannon-Wiener diversity index ranged from 1.74 (station 2) to 2.76 (station 7), with a mean value of $2.71 \pm 0.30$. Richness index and species number showed a similar trend, increasing with the distance from the coast. The richness index showed a significant positive correlation $(r=0.98$, $p<0.001$, Pearson's correlation) with species number. The evenness and Shannon-Wiener diversity indices did not show a clear trend, but were positively correlated with each other ( $r=0.785, p=0.021$, Pearson's correlation).

The most common copepod species in the present study were: Acrocalanus gracilis, Canthocalanus pauper, Subeucalanus subcrassus, Temora turbinata and Undinula vulgaris—all having a $100 \%$ occurrence rate (OR). Fifteen copepod species were exclusively identified from a single sample $(\mathrm{OR}=12.5 \%)$. Of all the samples, the top five abundant species were: Temora turbinata (relative abundance of $23.50 \%)$, Undinula vulgaris (17.92\%), Acrocalanus gibber (14.73\%), Canthocalanus pauper (11.49\%) and Acrocalanus gracilis ( $7.40 \%)$. The total numbers of the 


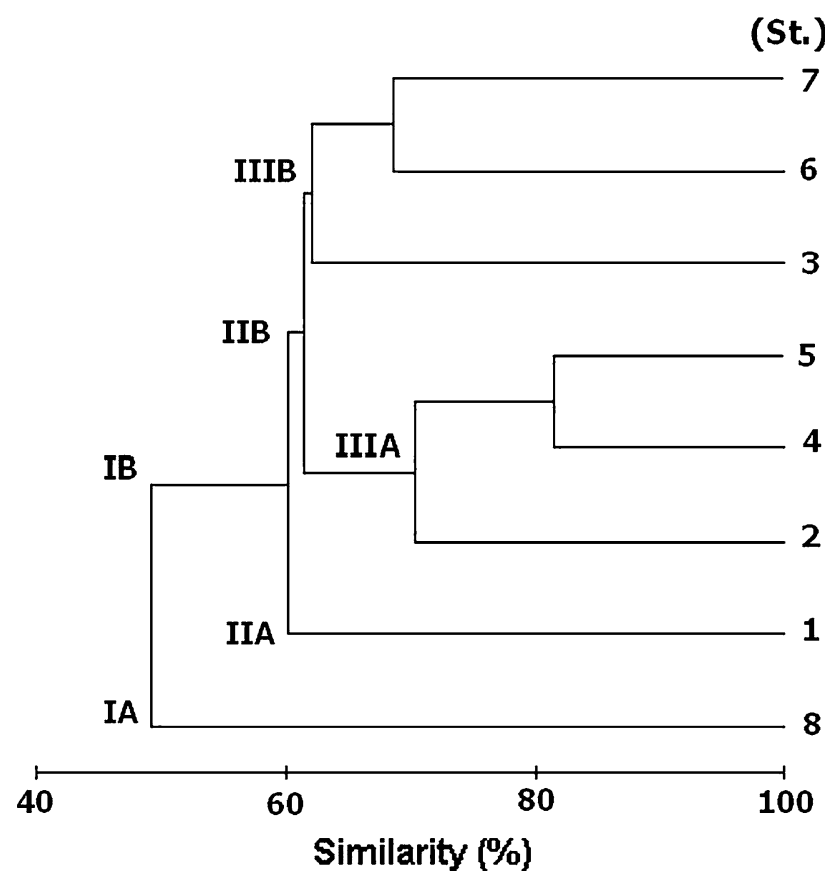

Fig. 7 Dendrogram indicating similarities between stations based on Bray-Curtis indexes for plankton composition

top five most abundant species contributed $75.04 \%$ to the total adundance of all samples (Table 3). Among all samples, the relative abundance of the indicator species $\mathrm{Cal}$ anus sinicus was $0.65 \%$, with an occurrence rate of $50.0 \%$, and an average density for the 8 sampling stations of $3.37 \pm 5.72$ individuals $\mathrm{m}^{-3}$ (Table 3 ).

Cluster analysis

The dendrogram (Fig. 7) shows the results of a clustering analysis based on Bray-Curtis similarities to characterize the copepod communities at the 8 sampling stations during the monsoon transition period. The values of IndVal were calculated for copepods with relative abundances above $5 \%$ (Table 4).
Station 8 is separated from the others and allocated to group IA. The top three dominant copepod species of group IA were: Canthocalanus pauper (31.93\%), Acrocalanus gracilis $(26.99 \%)$ and Temora turbinata $(11.09 \%)$. At the next grouping level, station 1 was separated as group IIA, which showed the lowest richness index (Fig. 6b) and a specific composition of copepod species. The top three dominant species of group IIA were: Temora turbinata (32.76\%), Canthocalanus pauper (19.83\%), and Acrocalanus gibber (10.34\%). In group IIA, two copepods, Temora turbinata $(32.76 \%)$ and Centropages furcatus $(6.90 \%)$ showed a higher proportion than in other cluster groups, and 7 species with relative abundances higher than $5 \%$. The third level (III) separated the remaining stations into two groups. Group IIIA (stations 2, 4 and 5) were closer to land than the stations of group IIIB (stations 3, 6 and 7). The three most dominant species of group IIIA were: Temora turbinata (25.05\%), Undinula vulgaris $(22.61 \%)$ and Acrocalanus gibber (20.47\%). The most dominant species of group IIIB were: Undinula vulgaris (17.89\%), Temora turbinata (13.92\%) and Canthocalanus pauper (13.02\%). The copepods Subeucalanus subcrassus $(10.85 \%)$ and Oncaea venusta $(5.35 \%)$ showed a higher abundance in group IIIB than in other groups. The results suggest that during the monsoon transition period copepod communities in the surface waters of northern Taiwan vary horizontally and with distance to land.

Correlations with environmental factors

Among all mesozooplankton taxa, the abundance of chaetognaths was negatively correlated with salinity $(r=$ 0.77, $p=0.027$, Pearson's correlation, Fig. 8a). In contrast, the group number of the mesozooplankton showed a positive correlation with salinity $(r=0.71, p=0.048$, Pearson's correlation, Fig. 8b). The abundance of Acrocalanus monachus ( $r=0.75, p=0.03$, Pearson's correlation, Fig. 8c) and copepod species number $(r=0.91$, $p=0.002$, Pearson's correlation, Fig. 8d) were also positively correlated with salinity. Species numbers increased

Table 4 Indicator value indexes of copepod species with more than 50\% OR (indicator species)

\begin{tabular}{|c|c|c|c|c|}
\hline \multirow[t]{2}{*}{ No. } & \multicolumn{4}{|l|}{ Indicator species (index value $\%$ ) } \\
\hline & I A & II A & III A & III B \\
\hline 1 & Canthocalanus pauper (31.93) & Temora turbinata $(32.76)$ & Temora turbinata (25.05) & Undinula vulgaris (17.89) \\
\hline 2 & Acrocalanus gracilis (26.99) & Canthocalanus pauper (19.83) & Undinula vulgaris (22.61) & Temora turbinata (13.92) \\
\hline 3 & Temora turbinata (11.09) & Acrocalanus gibber (10.34) & Acrocalanus gibber (20.47) & Canthocalanus pauper (13.02) \\
\hline 4 & Undinula vulgaris (9.95) & Temora discaudata (9.05) & Canthocalanus pauper (6.79) & Subeucalanus subcrassus (10.85) \\
\hline 5 & & Centropages furcatus (6.90) & Acrocalanus gracilis $(6.24)$ & Acrocalanus gracilis (10.62) \\
\hline 6 & & Undinula vulgaris (5.17) & & Acrocalanus gibber (6.17) \\
\hline 7 & & Calanopia minor (5.17) & & Oncaea venusta (5.35) \\
\hline
\end{tabular}



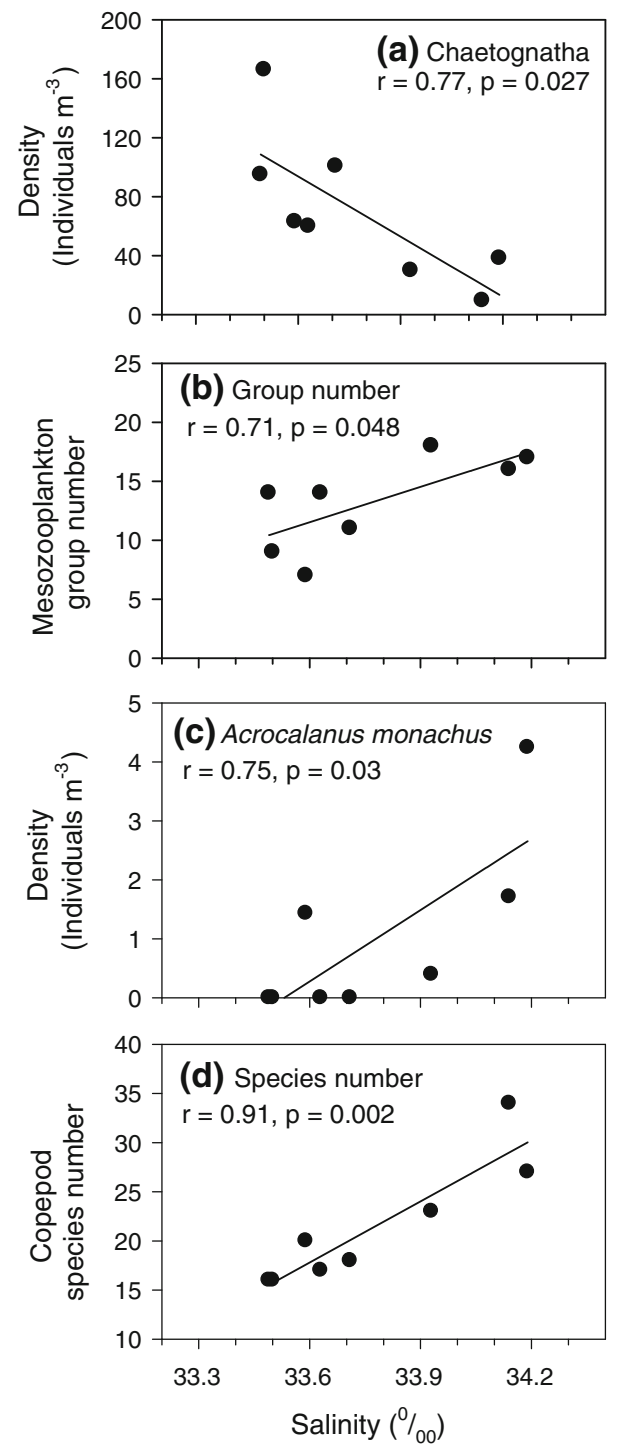

Fig. 8 Correlation between salinity and chaetognath density (a), number of mesozooplankton groups (b), densitiy of the copepod Acrocalanus monachus (c), and number of copepod species (d), showing significant correlations (Pearson's correlation analysis)

with increasing distance of the sampling stations from the coast.

Only a few mesozooplankton taxa showed changes in density which were significantly correlated with seawater temperature. The abundances of mesozooplanktonic amphipods ( $r=-0.79, p=0.019$, Pearson's correlation, Fig. 9a) and decapods ( $r=-0.81, p=0.014$, Pearson's correlation, Fig. 9b) were negatively correlated with seawater temperature, and this also applied to the following four copepod species: Calanus sinicus $(r=-0.85, p=$ 0.008, Pearson's correlation, Fig. 9c), Calocalanus pavo $(r=-0.74, p=0.035$, Pearson's correlation, Fig. 9d), Calanopia elliptica $(r=-0.72, p=0.044$, Pearson's correlation, Fig. 9e) and Labidocera acuta $(r=-0.82$, $p=0.013$, Pearson's correlation, Fig. 9f).

\section{Discussion}

Zooplankton communities in the ocean are influenced by several factors including river discharge (Tan et al. 2004), monsoons (Yoshida et al. 2006), urban runoffs and change of water masses (Tseng et al. 2008a). Tan et al. (2004) and Yoshida et al. (2006) reported copepods as the main fraction of mesozooplankton in the Pearl River estuary and the Malacca Strait, respectively. In the present study the dominant taxa of mesozooplankton were calanoid copepods $(66.36 \%)$, followed by chaetognaths $(9.44 \%)$. Huang (1983) studied the zooplankton communities in the upwelling waters off the southeastern coast of Taiwan, and reported calanoid copepods to be highly abundant (44.0-59.7\%) in all samples. Tseng et al. (2008a) found calanoid copepods to dominate $(37.07 \%)$ the mesozooplankton communities in an outfall area in the northeastern South China Sea. The results confirm calanoid copepods to be the dominant mesozooplankton taxon.

Another dominant species in the present study was the chaetognath Flaccisagitta enflata. This species is widely distributed in the coastal waters of mainland China (Chen 1992). Chen (1992) reported the the species to be abundant during summer and autumn in the waters of the boundary zone of the Yellow Sea and the ECS. According to PierrotBults and Nair (1991), the species is circum-globally distributed and commonly found between $40^{\circ} \mathrm{N}$ and $40^{\circ} \mathrm{S}$. Tse et al. (2008) found $F$. enflata to be a dominant species in the waters of Hong Kong. Tseng et al. (2011) reported the species to be abundant in the waters of the western and southern ECS during a summer cruise. The present study confirmed $F$. enflata to be abundant in the southern ECS during the SW-NE monsoon transition period. The amphipods Hyperioides sibaginis and Lestigonus bengalensis were common in the samples of the present study. $H$. sibaginis is distributed in the waters of eastern mainland China and has been reported in the South China Sea (Chen 1983; Lowry 2000), the Taiwan Strait (Lin and Chen 1988), and the ECS (Xu and Jiang 2006; Xu 2009). Our study shows that this species can occur in the southern ECS during the monsoon transition period.

Copepod communities change dynamically with water masses during northeast and southwest monsoons (Hsieh et al. 2004, 2005; Hwang et al. 2004, 2006, 2009; Dur et al. 2007; Tseng et al. 2008b). The dominant copepod species in the present study were: Temora turbinata, Undinula vulgaris, Acrocalanus gibber, Canthocalanus pauper and Acrocalanus gracilis. These species are warm-water species that are commonly found around Taiwan (Shih and 
Fig. 9 Correlation between seawater temperature and the densities of amphipods (a), decapods (b), and the copepods Calanus sinicus $(\mathbf{c})$,

Calocalanus pavo $(\mathbf{d})$, Calanopia elliptica (e) and Labidocera acuta (f), showing significant correlations (Pearson's correlation analysis)
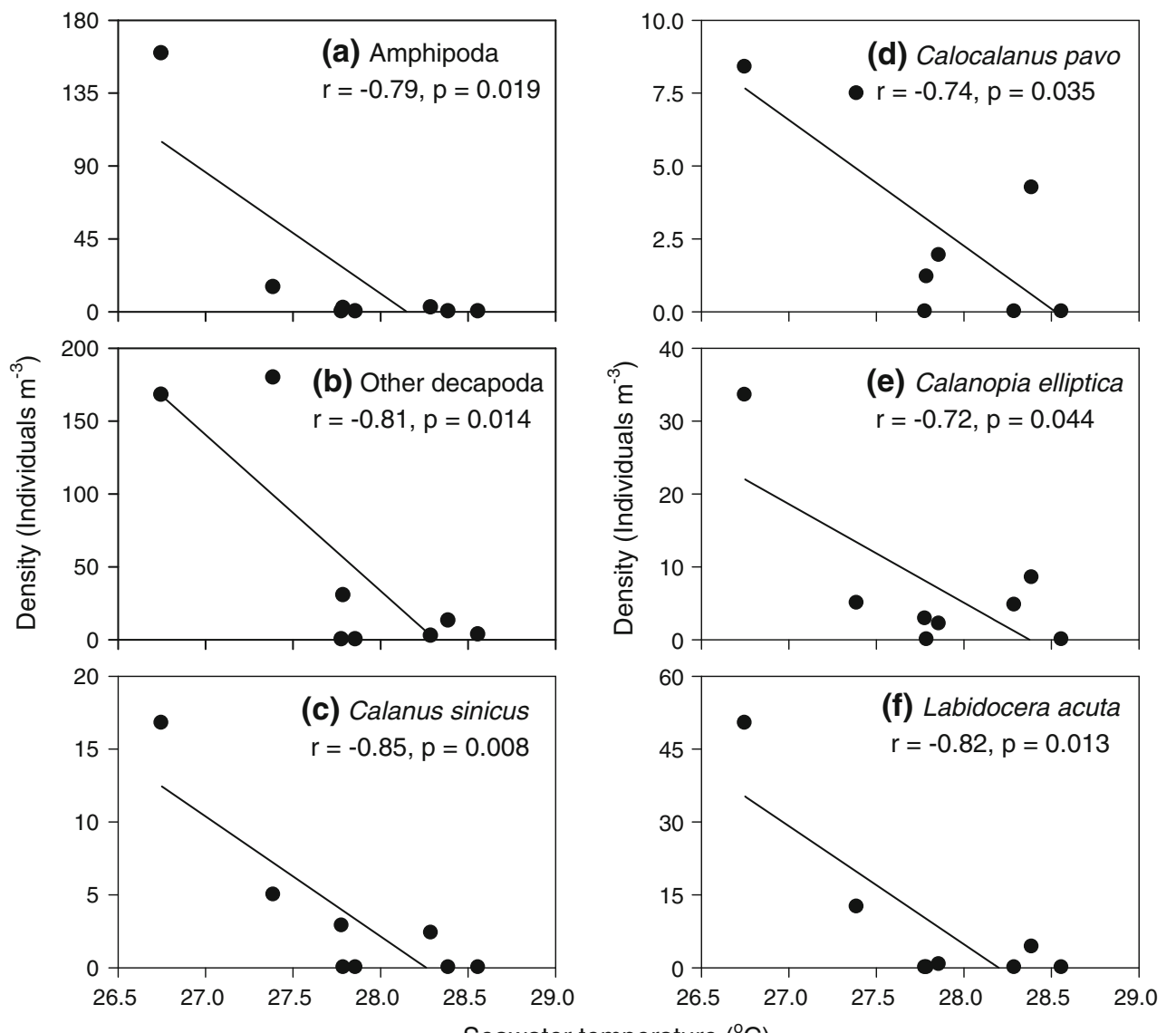

Young 1995; Hwang et al. 2004; Dur et al. 2007; Tseng et al. 2008d, 2011b). Temora turbinata is an indicator species of warm water masses (Dur et al. 2007; Tseng et al. 2008b) which can also tolerate polluted environments (Fang et al. 2006; Tseng et al. 2008e; Wu et al. 2010).

A limited number of studies reported a seasonal succession of copepods in the waters north of Taiwan (Hwang et al. 2004, 2006; Hwang and Wong 2005; Dur et al. 2007; Tseng et al. 2008b). These studies included different types of coastal areas, including areas such as those close to nuclear power plants (Hwang et al. 2004), the estuary of the Danshuei River (Dur et al. 2007; Hwang et al. 2006, 2009), and the northeastern Taiwan Strait (Tseng et al. 2008b). Previous reports indicated that the calanoid copepod $C$. sinicus belongs to the cold-water masses of the CCC that derive from the Yellow Sea during the northeast monsoon. Previous reports never found $C$. sinicus in summer samples from the coastal areas. However, this species was frequently recorded with high rates of occurrence and relative abundance from October to April. Previous reports did not provide information about copepod composition in the waters north of Taiwan in September. This may be due to a lack of data collection in September.
To date, there is no information on when $C$. sinicus first arrives in the waters of northern Taiwan from its probable origin in the Bohai Sea. Our results show that $C$. sinicus was present in the sampling area in September 1998, before the CCC affected the coastal areas of northern Taiwan. This is clearly shown by the contemporaneous satellite images of the sea surface temperature (Fig. 2), indicating that the colder waters of the CCC were still separated from the study area. Contrary to previous studies (Hwang et al. 2004, 2006; Hwang and Wong 2005; Dur et al. 2007; Tseng et al. 2008b) that suggest $C$. sinicus to be exclusively transported by the cold CCC water, we demonstrate that C. sinicus is present in the southern ECS even during the northeast monsoon transit period. However, it cannot be excluded that $C$. sinicus survives in the deeper layers of the ECS when surface waters seasonally warm up, sinking to deeper water during summer and returning to surface waters via cold upwelling or vertical migration.

Previous field studies reported $C$. sinicus in the south ECS close to the present area of study. Hsieh et al. (2004) still reported $C$. sinicus north of the Taiwan Strait when the northeast monsoon was prevailing. Liao et al. (2006) found C. sinicus occurred in August at the upwelling area of the 
Table 5 Number of copepod species identified in different parts and during different periods in the East China Sea (ECS)
${ }^{\text {a }}$ Only calanoid copepods recorded

\begin{tabular}{|c|c|c|c|}
\hline Area of ECS & $\begin{array}{l}\text { Number of } \\
\text { identified } \\
\text { species }\end{array}$ & Study period & References \\
\hline Southwestern (Tanshui) & 83 & June/1970 & Tseng (1975) \\
\hline Southwestern (Tanshui River estuary) & 62 & $\begin{array}{l}\text { August/1996-January/ } \\
1997\end{array}$ & $\begin{array}{l}\text { Hsieh and Chiu } \\
\text { (1997) }\end{array}$ \\
\hline Southern (Coastal water) & $25^{\mathrm{a}}$ & May/1996 & Hwang et al. (1998) \\
\hline Southern (Nuclear power plants) & $37^{\mathrm{a}}$ & August/1996 & Wong et al. (1998) \\
\hline Southern (North of Taiwan) & 113 & April/1995 & $\begin{array}{l}\text { Shih and Chiu } \\
\text { (1998) }\end{array}$ \\
\hline Southern (North of Taiwan) & 183 & March/1995 & Shih et al. (2000) \\
\hline Southeastern (Upwelling water) & 178 & March/1995 & Lo et al. (2004b) \\
\hline Southern (Nuclear power plants) & 116 & $\begin{array}{l}\text { November/2000-December/ } \\
2003\end{array}$ & Hwang et al. (2004) \\
\hline $\begin{array}{l}\text { Southwestern (Boundary coastal } \\
\text { waters) }\end{array}$ & 110 & $\begin{array}{l}\text { October/1998-September/ } \\
2003\end{array}$ & Hwang et al. (2006) \\
\hline Southeastern (Upwelling water) & 95 & August/1998 & Liao et al. (2006) \\
\hline $\begin{array}{l}\text { Southwestern (Estuary of Danshuei } \\
\text { River) }\end{array}$ & $79^{\mathrm{a}}$ & $\begin{array}{l}\text { October/1998-July/ } \\
2004\end{array}$ & Dur et al. (2007) \\
\hline Southwestern area & 77 & July/2001 & Tseng et al. (2008d) \\
\hline $\begin{array}{l}\text { Southwestern (Estuary of Danshuei } \\
\text { River) }\end{array}$ & 120 & $\begin{array}{l}\text { October/1998-July/ } \\
2004\end{array}$ & Hwang et al. (2009) \\
\hline Southern area & 49 & September/1998 & Present study \\
\hline
\end{tabular}

southeastern ECS. Their study indicated that $C$. sinicus occasionally occurred at low abundances. They suggested that $C$. sinicus was coming from the north of the Taiwan Strait with the Taiwan Strait warm current. Chen (1992) reported that the temperature range of $C$. sinicus was $5-23^{\circ} \mathrm{C}$. Therefore, Liao et al. (2006) inferred that C. sinicus in fact comes from the waters of the northern Taiwan Strait and later appears at the surface due to upwelling. In the present study we found three more species related to cold-water masses: Calocalanus pavo, Calanopia elliptica and Labidocera acuta, which are temperate species originating from the ECS (Chen 1992).

The copepod species numbers found in the southern ECS varied in different studies according to sampling location and study period (Table 5). The two studied areas with high species numbers were located in the upwelling zone (Shih et al. 2000; Lo et al. 2004b; Liao et al. 2006) and in the southwest ECS in the estuary of Danshuei River (Hwang et al. 2009). Upwelling areas with higher primary productivity commonly support a higher biodiversity of secondary producers (Nybakken 1993). Liao et al. (2006) reported 95 species in the upwelling waters of the southeast ECS with higher species richness than previously reported from coastal areas (Hwang et al. 1998; Wong et al. 1998). Station 5 of the present study was located close to the upwelling area and showed the highest density of mesozooplankton of the 8 sampling stations. Shih et al. (2000) and Lo et al. (2004b) found 178 and 183 species, respectively, in the upper $250 \mathrm{~m}$ water layer. Similarly, Shih and
Chiu (1998) recorded 113 species in the upper $200 \mathrm{~m}$. To date, most ecological studies of copepod communities were performed in the southwestern ECS and the estuary of the Danshuei River (Tseng 1975; Hwang et al. 2006, 2009; Dur et al. 2007). This includes a longer study period of 6 years (Hwang et al. 2009). Hwang et al. (2004) identified 116 copepod species during a 3-year study close to the nuclear power plants I and II in the northeastern coastal area of Taiwan, and 120 species were reported off the Danshui Estuary during a 6-year study (Hwang et al. 2009). The previous studies showed that the number of identified copepod species increased with the temporal and spatial scale of the investigations.

The present study was carried out during the monsoonal transition period before the onset of the northeast monsoon in late summer. The SST image did not provide any evidence that the coastal areas of northern Taiwan were affected by the CCC during the study period. Nevertheless, we identified $C$. sinicus in northern Taiwan waters. Future studies should focus on the deeper water layers of the ECS to see whether $C$. sinicus uses the cold water stratum as a refuge during the seasons with warm surface waters.

Acknowledgments We thank Mr. Hsuan-Chan Wang for his assistance in the field work. Particular acknowledgement is given to the Department of Atmospheric Science at the National Taiwan University for providing us with the weather information (data bank for atmospheric research). We are thankful to anonymous reviewer and editor, whose comments and suggestions substantially improved the manuscript. 


\section{References}

Box GEP, Cox DR (1964) An analysis of transformations (with discussion). J Roy Stat Soc Ser B 26:211-246

Chang YC, Yan JC, Hwang JS, Wu CH, Lee MT (2011) Dataoriented analyses of ciliate foraging behaviors. Hydrobiologia 666:223-237

Chen RX (1983) The planktonic amphipods in the East and South China Seas. Collect Ocean Works 6:76-92

Chen QC (1992) Zooplankton of China Seas (1). Science Press, Beijing

Chen QC, Zhang SZ (1965) The planktonic copepods of the Yellow Sea and the East China Sea. I. Calanoida. Studia Marina Sinica 7: 20-131, 53 plates (in Chinese, with English summary)

Chen QC, Zhang SZ, Zhu CS (1974) On planktonic copepods of the Yellow Sea and the East China Sea. II. Cyclopoida and Harpacticoida. Studia Marina Sinica 9: 27-76, 24 plates, (in Chinese, with English summary)

Chihara M, Murano M (1997) An illustrated guide to marine plankton in Japan. Tokyo University Press, Tokyo

Clarke KR, Warwick RM (1994) Change in marine communities: an approach to statistical analysis and interpretation. Plymouth Marine Laboratory \& Primer-E, Plymouth

Dahms HU, Hwang JS (2007) Krill-tracking by ROV in the Antarctic. J Ocean Underw Technol 17:3-8

Dahms HU, Hwang JS (2010) Underwater optics as a tool in Oceanography. J Mar Sci Technol 18:112-121

Dufrêne M, Legendre P (1997) Species assemblages and indicator species: the need for a flexible asymmetrical approach. Ecol Monogr 67:345-366

Dur G, Hwang JS, Souissi S, Tseng LC, Wu CH, Hsiao SH, Chen QC (2007) An overview of the influence of hydrodynamics on the spatial and temporal patterns of calanoid copepod communities around Taiwan. J Plankton Res 29(Supplement 1):i97-i116

Fang TH, Hwang JS, Shiao SH, Chen HY (2006) Trace metals in seawater and copepods in the ocean outfall area off the northern Taiwan coast. Mar Environ Res 61:224-243

Hsiao SH, Lee CY, Shih CT, Hwang JS (2004) Calanoid copepods of the Kuroshio Current east of Taiwan, with a note on the presence of Calanus jashnovi Hulseman, 1994. Zool Stud 43:323-331

Hsieh CH, Chiu TS (1997) Copepod abundance and species composition of Tanshui River estuary and adjacent waters. Acta Zool Taiwan 8:75-83

Hsieh CH, Chiu TS, Shih CT (2004) Copepod diversity and composition as indicators of intrusion of the Kuroshio Branch Current into the Northern Taiwan Strait in Spring 2000. Zool Stud 43:393-403

Hsieh CH, Chen CS, Chiu TS (2005) Composition and abundance of copepod and ichthyoplankton in the Taiwan Strait (western North Pacific) in relation to seasonal marine conditions. Mar Freshw Res 56:153-161

Huang CC (1983) Zooplankton communities in the upwelling water off the southeastern coast of Taiwan. Acta Oceanogr Taiwan 14:136-145

Hwang JS, Wong CK (2005) The China Coastal Current as a driving force for transporting Calanus sinicus (Copepoda: Calanoida) from its population centers to waters of Taiwan and Hong Kong during the NE monsoon period in winter. J Plankton Res 27:205-210

Hwang JS, Chen QC, Wong CK (1998) Taxonomic composition and grazing rate of calanoid copepods in coastal waters of northern Taiwan. Crustaceana 71:378-389

Hwang JS, Tu YY, Tseng LC, Fang LS, Souissi S, Fang TH, Lo WT, Twan WH, Hsiao SH, Wu CH, Peng SH, Wei TP, Chen QC (2004) Taxonomic composition and seasonal distribution of copepod assemblages from waters adjacent to nuclear power plant I and II in northern Taiwan. J Mar Sci Technol 12:380-391

Hwang JS, Souissi S, Tseng LC, Seuront L, Schmitt FG, Fang LS, Peng SH, Wu CH, Hsiao SH, Twan WH, Wei TP, Kumar R, Fang TH, Chen QC, Wong CK (2006) A 5-year study of the influence of the northeast and southwest monsoons on copepod assemblages in the boundary coastal waters between the East China Sea and the Taiwan Strait. J Plankton Res 28:943-958

Hwang JS, Dahms HU, Tseng LC, Chen QC (2007) Intrusions of the Kuroshio Current in the northern South China Sea affect copepod assemblages of the Luzon Strait. J Exp Mar Biol Ecol 352:12-27

Hwang JS, Souissi S, Dahms HU, Tseng LC, Schmitt FG, Chen QC (2009) Rank-abundance allocations as a tool to analyze planktonic copepod assemblages off the Danshuei estuary (Taiwan). Zool Stud 48:49-62

Hwang JS, Kumar R, Dahms HU, Tseng LC, Chen QC (2010a) Interannual, seasonal, and diurnal variation in vertical and horizontal distribution patterns of 6 Oithona spp. (Copepoda: Cyclopoida) in the South China Sea. Zool Stud 49:220-229

Hwang JS, Kumar R, Hsieh CW, Kuo AY, Souissi S, Hsu MH, Wu JT, Liu W, Wang CF, Chen QC (2010b) Patterns of zooplankton distribution along the marine, estuarine and riverine portions of the Danshuei ecosystem in northern Taiwan. Zool Stud 49: 335-352

Jan S, Wang J, Chern CS, Chao SY (2002) Seasonal variation of the circulation in the Taiwan Strait. J Mar Syst 35:249-268

Lan YC, Shih CT, Lee MA, Shieh HZ (2004) Spring distribution of copepods in relation to water masses in the northern Taiwan Strait. Zool Stud 43:332-343

Lan YC, Lee MA, Liao CH, Lee KT (2009) Copepod community structure of the winter frontal zone induced by the Kuroshio Branch Current and the China Coastal Current in the Taiwan Strait. J Mar Sci Technol 17:1-6

Lee HJ, Chao SY (2003) A climatological description of circulation in and around the East China Sea. Deep-Sea Res II 50:1065-1084

Liang WD, Tang TY, Yang YJ, Ko MT, Chuang WS (2003) Upperocean currents around Taiwan. Deep-Sea Res II(50):1085-1106

Liao CH, Lee KT, Lee MA, Lu HJ (1999) Biomass distribution and zooplankton composition of the sound-scattering layer in the waters of southern East China Sea. ICES J Mar Sci 56:766-778

Liao CH, Chang WJ, Lee MA, Lee KT (2006) Summer distribution and diversity of copepods in upwelling waters of the Southeastern East China Sea. Zool Stud 45:378-394

Lin JH, Chen RX (1988) Distribution of the planktonic amphipoda in western Taiwan Strait. J Oceanogr Taiwan Strait 7:324-330

Lo WT, Hwang JS, Chen QC (2001) Identity and abundance of surface dwelling, coastal copepods of southwestern Taiwan. Crustaceana 74:1139-1157

Lo WT, Hwang JS, Chen QC (2004a) Spatial variations of copepods in the surface waters of southeastern Taiwan Strait. Zool Stud 43:218-228

Lo WT, Shih CT, Hwang JS (2004b) Diel vertical migration of the planktonic copepods at an upwelling station north of Taiwan, western North Pacific. J Plank Res 26:89-97

Lowry JK (2000) Taxonomic status of amphipod crustaceans in the South China of known species. Raffles Bull Zool Suppl 8:309-342

Mahjoub MS, Souissi S, Dur G, Schmitt FG, Nan FH, Hwang JS (2011) Anisotropy and shift of search behavior in Malabar grouper (Epinephelus malabaricus) larvae in response to prey availability. Hydrobiologia 666:215-222

Nybakken JW (1993) Marine biology: an ecological approach, 3rd edn. Harper Collins College, New York 
Pierrot-Bults AC, Nair R (1991) Distribution patterns in Chaetognatha. In: Bone Q, Kapp H, Pierrot-Bults AC (eds) The biology of chaetognaths. Oxford University Press, Oxford, pp 86-116

Shao KT (1998) Marine ecology. National Press Company, Ming Wen Book Co., Ltd, Taipei (in Chinese)

Shih CT, Chiu TS (1998) Copepod diversity in the water masses of the southern East China Sea north of Taiwan. J Mar Syst 15:533-542

Shih CT, Young SS (1995) A checklist of free-living copepods, including those associated with invertebrates, reported from the adjacent seas of Taiwan. Acta Zool Taiwanica 6:65-81

Shih CT, Hwang JS, Huang WB (2000) Planktonic Copepods from an Upwelling Station North of Taiwan, Western North Pacific. J Taiwan Mus 10:19-35

Tan Y, Huang L, Chen Q, Huang X (2004) Seasonal variation in zooplankton composition and grazing impact on phytoplankton standing stock in the Pearl River Estuary, China. Cont Shelf Res 24:1949-1968

Tse P, Souissi S, Hwang JS, Chen QC, Wong CK (2008) Spatial and seasonal variations in chaetognath assemblages in two subtropical marine inlets with different hydrographical characteristics. Zool Stud 47:258-267

Tseng WY (1975) Planktonic copepods from the waters off Tansui. Bull Taiwan Fish Res Inst 25:1-44 (in Chinese)

Tseng LC, Kumar R, Dahms HU, Chen CT, Chen QC, Hwang JS (2008a) Epipelagic mesozooplankton succession and community structure above a marine outfall in the northeastern South China Sea. J Environ Biol 29:275-280

Tseng LC, Kumar R, Dahms HU, Chen QC, Hwang JS (2008b) Monsoon driven seasonal succession of copepod assemblages in the coastal waters of the northeastern Taiwan Strait. Zool Stud 47:46-60

Tseng LC, Kumar R, Dahms HU, Chen QC, Hwang JS (2008c) Copepod gut contents, ingestion rates and feeding impact in relation to their size structure in the southeastern Taiwan Strait. Zool Stud 47:402-416

Tseng LC, Souissi S, Dahms HU, Chen QC, Hwang JS (2008d) Copepod communities related to water masses in the southwest East China Sea. Helgol Mar Res 62:153-165

Tseng LC, Kumar R, Dahms HU, Chen CT, Souissi S, Chen QC, Hwang JS (2008e) Copepod community structure over a marine outfall area in the northeastern South China Sea. J Mar Biol Assoc UK 88:955-966

Tseng LC, Dahms HU, Chen QC, Hwang JS (2009) Copepod feeding study in the upper layer of the tropical South China Sea. Helgol Mar Res 63:327-337

Tseng LC, Kumar R, Chen QC, Hwang JS (2011a) Summer distribution of Noctiluca scintillans and mesozooplankton in the Western and Southern East China Sea prior to the Three Gorges Dam operation. Hydrobiologia 666:239-256

Tseng LC, Kumar R, Chen QC, Hwang JS (2011b) Faunal shift between two copepod congeners (Temora discaudata and T. turbinata) in the vicinity of two nuclear power plants in southern East China Sea: spatiotemporal patterns of population trajectories over a decade. Hydrobiologia 666:301-315

Vandromme P, Schmitt FG, Souissi S, Buskey EJ, Strickler JR, Wu CH, Hwang JS (2010) Symbolic analysis of plankton swimming trajectories: case study of Strobilidium sp. (Protista) Helical Walk under various food conditions. Zool Stud 49:289-303

Wong CK, Hwang JS, Chen QC (1998) Taxonomic composition and grazing impact of calanoid copepods in coastal waters near nuclear power plants in northern Taiwan. Zool Stud 37:330-339

Wong GTF, Chao SY, Li YH, Shiah FK (2000) The Kuroshio edge exchange processes (KEEP) - interactions between the East China Sea and the Kuroshio. Cont Shelf Res 20:331-635

Wu CH, Dahms HU, Buskey EJ, Strickler JR, Hwang JS (2010) Behavioral interactions of the copepod Temora turbinata with potential ciliate prey. Zool Stud 49:157-168

$\mathrm{Xu} \mathrm{Z} \mathrm{(2009)} \mathrm{Statistical} \mathrm{analysis} \mathrm{on} \mathrm{ecological} \mathrm{adaptation} \mathrm{of} \mathrm{pelagic}$ amphipoda in the East China Sea. Acta Oceanol Sinica 28:61-69

Xu Z, Jiang M (2006) Distribution pattern of pelagic amphipods and its affecting facors in the East China Sea. Acta Oceanol Sinica $25: 112-119$

Yoshida T, Toda T, Yusoff FM, Othman BHR (2006) Seasonal variation in zooplankton community in the coastal waters of the Straits of Malacca. Cstl Mar Sci 30:320-327

Zuo T, Wang R, Chen YQ, Gao SW, Wang K (2006) Autumn net copepod abundance and assemblages in relation to water masses on the continental shelf of the Yellow Sea and East China Sea. J Mar Syst 59:159-172 